\title{
The Russian Policy and the Intensification of Civil Wars in Georgia, Tajikistan and Moldova
}

\author{
Alexander Benifand
}

There are more than two million refugees in Russia, most of whom are in Moscow, St. Petersburg, the Krasnodar, Stavropol and Rostov regions. Even in the Siberian Altai region there are about 20,000 refugees roaming the Kulunda steppe in search of help. They have come from Central Asia, Transcaucasia, Tatarstan, Tula, Buryatia, Bashkiria and Yakutia. About 90 percent are Russians and the others are Germans, Ossetians, Kazakhs and Moldovans.

In the vast territory of what used to be the Soviet Union and its satellites, there is clear potential for many Yugoslavia-type civil wars. Many of these countries share the preconditions for armed conflict: the collapse of strong central authority, economic crises, persistent violations of minority rights, border disputes and very limited experience with democracy.

A profound economic crisis plays a significant role in intensifying social and ethnic conflicts. In the first quarter of 1992 alone, the Russian economy declined by 14 percent. An opinion poll conducted by a sociologist, Boris Grushin, in the Russian Federation, produced the following results: 80 percent of the people felt that life was better before perestroika than now; 67 percent of the respondents favoured socialism; and 50 percent of the respondents (predominantly older people) have favourable thoughts about Stalin. ${ }^{1}$ Under these conditions, patriotic and nationalist forces are gaining more influence and popular support. Because the economic reforms have failed to bring prosperity and stabilize the Russian economy, many active members of the democratic movement are looking for answers among the conservatives and nationalists.

Ultranationalist forces attack Yeltsin's reforms. They hope to restore

Alexander Benifand is a visiting research fellow at the Centre for Research Studies.
Russia's glory. The idea of a great Russian empire holds strong appeal for the masses. The emerging nationalist ideology produces xenophobia inside Russia and a sense of solidarity with twenty-five million Russians living outside Russia in the former Soviet republics. This concern about the violation of rights of Russian minorities in the Baltics and other newly formed states is shared by those in the democratic movement. What distinguishes the nationalists is that they also view Russian ethnic minorities as the "fifth column" in their struggle to restore the Russian empire.

Furthermore, some argue that the entire landscape of the former U.S.S.R. is of vital geopolitical interest to Russia. ${ }^{2}$ Yevgeny Ambartsumov, chairman of the Supreme Soviet's Joint Committee on International Affairs and Foreign

\section{In the vast territory of what used to be the Soviet Union and its satellites, there is clear potential for many Yugoslavia-type civil wars.}

Economic Relations, has made the following recommendations on Russian foreign policy: "As the internationally recognized legal successor to the U.S.S.R., the Russian Federation should base its foreign policy on a doctrine declaring the entire geopolitical space of the former Union to be the sphere of its vital interests ... and should strive to achieve understanding and recognition from the world community of its special interests in this space." ${ }^{3}$

Yeltsin is walking on quicksand. His political rating has dropped significantly. To stay in power he is moving more and more towards conservative forces. He is hoping to raise his popularity by placing the issue of the protection of minority rights of Russians on the negotiation table with other CIS and Baltic states. More importantly, the Russian government wishes to maintain its everpresent influence throughout the former Soviet Union.

Russia moves very slowly towards the withdrawal of its troops from the Baltic, Moldova and other regions. It also interferes in internal affairs of the CIS states by sending troops to contain the conflicts and protect the rights of the Russian minorities. One example is the Russian policy in Abkhazia (Georgia), Moldova and Tajikistan.

\section{ABKHAZIA}

The armed confrontation between Abkhaz and Georgian forces began before the dissolution of the U.S.S.R. Political turmoil started when Abkhazia, which used to be a part of the Georgian Soviet Socialist republic, declared independence. After the formation of the Georgian independent state, Abkhazia continued its struggle for independence. However, the heterogeneous ethnic composition of the region complicates matters. There are 90,000 Muslim Abkhazians living among 500,000 Christian Georgians, Russians and Armenians in Abkhazia. They constitute only 17 percent of the region's population. The remainder are 46 percent Georgians, 15 percent Russians and 15 percent Armenians. ${ }^{4}$

Originally two parties were involved in the conflict: the Abkhaz and the Georgian National Guards. In addition, the Abkhazian struggle attracts volunteers from the mountain peoples of Northern Caucasus, which is presently part of Russia. ${ }^{5}$ The confederation of mountain people issued an ultimatum to Georgia to withdraw its troops from Abkhazia and pay compensation for the damage it caused. If Georgia did not comply, the confederation threatened to declare the start of hostilities against Georgia. 
Abkhazia has tremendous strategic significance by virtue of its location on the Black Sea. Most important ports are located there. Furthermore, a major railroad also crosses the region. It is no wonder that Russia is very interested in its fate.

Originally Russian troops arrived in Abkhazia by invitation from the Abkhaz Parliament, which argued that Russia could not remain indifferent to the situation in Abkhazia as some 90,000 Russianslivethere. The Abkhaz were hoping that Russia would beable to protect them from Georgia's control. This invitation played into the hands of Russian nationalists and those wishing to protect Russia's economicinterests there. Theidea of sending troops to Abkhazia was supported by the Russian Parliament. Russian President Boris Yeltsin told the Russian Supreme Soviet that Russia would not stand by while Russian citizens' interests were being trampled on, nor would Russian troops hesitate to defend themselves if attacked. Political observers say the Abkhaz conflict is being used by Yeltsin's hard-liner opponents in Parliament as a test of the president's devotion to important national causes.

Even though Yeltsin claims that the Russian forces would maintain neutrality, the Georgian State Council Chairman Eduard Shevardnadze accused Russian troops of transferring military technology to the Abkhaz forces and creating obstacles to Georgian forces. Russian troops are blocking the airspace of Georgia in the Abkhazian region and sea approaches. The Georgian foreign minister said, "This is a clear demonstration of the violation of the norms of international law, and crude trampling on the sovereignty of Georgia."

Yeltsin's policy is criticized both inside Russia and abroad. One political observer said, "It would be ironic if the great defender of freedom and democracy was forced to enter an essentially imperialist Soviet-style war." 6

Even before the Russian troops were sent to the region, the armed confrontation in Abkhazia has claimed hundreds of lives. Thousands of people have been uprooted. With the Russian troops there, the situation has become more complicated.It is expected that masses of people will become refugees. On January 5, 1993 Edward Shevardnadze asked the UN to send a peacekeeping force to Abkhazia.

\section{MOLDOVA (TRANS-DNIESTRIA)}

Present ethnic conflicts in TransDniestria have long historic roots. When Stalin masterminded the U.S.S.R., he put delayed-action bombs against the structure, i.e., conflicts in border regions. Trans-Dniestria is one of such places. In the twentieth century, the area frequently changed its masters. At first, the zone was part of the Kherson Region and then the Odessa Region (presently in Ukraine). During the Civil War (1919-21) it was successively occupied by Germans, Denikin's troops, French, Romanians and finally by the Red Army. Afterwards, the Tiraspol area was incorporated into the Odessa Region. Then it
On June 23, 1990 the Supreme Soviet of the Moldavian Soviet Socialist Republic passed a declaration on sovereignty and a document denouncing the Ribbentrop-Molotov Pact as an act of aggression and unlawful occupation of part of Romania's territory and the August 2, 1940 decision of the U.S.S.R. Supreme Soviet to establish the M.S.S.R. Moscow was thrown into commotion. The office of Anatoly Lukyanov (a former Parliament speaker and one of the organizers of the August 19 coup) started negotiating with representatives of the Russian and Gagauz population, stirring their separatist feelings and encouraging them to create two independent republics-Trans-Dniestria and Gagauzia. ${ }^{7}$ On September 2, 1990 deputies at all levels from the Left Bank districts of Moldova proclaimed the establishment of a Trans-Dniestria Moldavian Autonomous Soviet Socialist

\section{Abkhazia has tremendous strategic significance by virtue of its location on the Black Sea. Most important ports are located there. Furthermore, a major railroad also crosses the region. It is no wonder that Russia is very interested in its fate.}

became the Moldavian Autonomous Soviet Socialist Republic and eventually the Moldavian Soviet Socialistic Republic. In 1941-44 the territory was occupied by Romania, and was included afterwards into the Moldavian Autonomous Republic again. However, local people were never once asked their opinion. The change-over was forced upon them each time. As a result, local people of all ethnic backgrounds began to hate all forced changes.

The independent Moldova is seeking its identity as a European nation, perhaps as part of Romania, into which some hope to become incorporated in the future. But this means that residents of the strip of land along the Dniestria are again going to be included into the Balkan system. The Russians, who comprise a significant part of the 800,000 people in this area, do not look favourably at this development. Their demands for autonomy and independence from Moldova is fuelled by Moscow.
Republic as part of Moldova, but with a firm intention to remain part of the U.S.S.R.

The first sessions of Moldova's Parliament, elected in February-March 1990, was marked by the triumph of the nationalist idea. At the Congress of the Popular Front of Moldova (PFM), held in late June 1990, a resolution was passed, which recommended that Parliament rename the Moldavian Soviet Socialist Republic into the Romanian Republic of Moldova. The horror of unification was widespread in Trans-Dniestria. On August 25, 1991 the Supreme Soviet in Tiraspol (Trans-Dniestria) proclaimed the independence of the Left Bank. On September 6 a resolution was passed on the transfer of everything-from enterprises to the KGB - to the "young republic's" jurisdiction. During this time no one on the Left Bank was willing to negotiate a new state set-up of the Republic of Moldova. Moldova did not try to follow 
the route of political negotiation and used the diplomacy of guns.

On June 19-21, 1992 the city of Bendery was heavily shelled. The Bendery slaughter claimed 620 lives and left 3,500 wounded. Thousands of refugees from this region fled Russia, Ukraine and other parts of Moldova. This massacrelefta verybitter after-taste. Federation with Moldova is completely out of the question. At the same time, the Russian presence in the region is evergrowing. The 14th Army (which is under the Russian jurisdiction) is permanently stationed there under the command of Alexander Lebed, a former deputy com- set up a satellite on the territory to which it has no claim, since Trans-Dniestria is located between Moldova and Ukraine. The artificiality of this territorial creation has a potential for intensifying serious ethnic, territorial and political conflicts in the future.

\section{CENTRAL ASIA}

The uprooting of people in Tajikistan is caused by an armed conflict between two political forces. On the one side there are supporters of the former president Rakhmon Nabiev, supported by the Communist forces, whose leaders traditionally came from the economically de-

\section{... the war in Tajikistan ... will reach beyond the boundaries of Tajikistan because of ethnic kinships, the weakness of statehood and the absence of borders.}

mander of the Air Force of Russia. At his first press conference, Lebed firmly stated that Trans-Dniestria is Russian land. At the beginning of October, the "Dniestria republic" leaders in eastern Moldova celebrated the bicentennial of the founding of Tiraspol as a would-be capital of a military settlement of the Russian empire.

Trans-Dniestria intends to form its own army with the help of the 14th Army.Ministries of defence and national security have already been established. The Dniestria leaders passed an edict, imposing the Russian alphabet instead of the Latin alphabet on the Moldovan language of the region. Russian ultranationalist supporters of the "Dniestria republic" hail the progress of "this first republic free of democrats." The Council of Atamans of Russian Cossack Hosts, which convened in Tiraspol, asked Yeltsin to recognize the "Dniestria republic" and give it assistance, including military. ${ }^{8}$ The Abkhazian and "Dniestria" authorities have signed an alliance agreement. ${ }^{9}$

By maintaining its army on the territory of Trans-Dniestria, setting up institutions (such as banks and security) directly linked to those in Russia, and lending moral and material support to the Trans-Dniestria government, Russia veloped northern part of the country where Islamic influence is relatively weak. His opposition, which seized power from him in May 1992, is a weak coalition of prodemocracy and Islamic forces from the economically depressed south, where Communism did not take root. ${ }^{10}$

The first six months of the war caused 20,000 casualties. ${ }^{11}$ It also produced a massive displacement of people. Refugees escaping the fighting in southern Tajikistan have fled into Dushanbe, the capital of Tajikistan. Thousands of refugees from Kurgan-Tyube, the opposition stronghold, have picketed the Russian ambassador's residence demanding an end to Russian interference in Tajikistan. According to the ITAR-TASS report of December 31, there were 537,000 refugees officially registered in Tajikistan and around 70,000 who fled to Afghanistan (Radio Free Europe, January 4, 1993). This was a reaction to rumours that the Russian forces have given weaponry and equipment to supporters of deposed president Rachmon Nabiev. Leaders of the opposing sides in the civil war say they have no control over 20 percent of their forces.

The situation is analogous to Afghanistan not only because the latter is Tajikistan's neighbour and its ethnic rela- tive, but also because this strategically important region, rich in natural resources, particularly uranium, has become an object of external pressure by various groups of the Mojahedin, Iranians, Turks and Uzbeks. This pressure intensified the disintegration of Tajik society in political and regional terms. The northern part of Tajikistan is drawn towards Uzbekistan, while the southern region is immersed in a civil war that is becoming part of Afghan feuding. Russia cannot stand aloof in the Tajik conflict, which threatens 600,000 Russians living in the republic and jeopardizes Russia's interests. Therefore, there is a strong Russian military presence there.

Some Russian political analysts, such as Vladimir Kulistikov, believe that the war in Tajikistan may have wider regional implications. This war will reach beyond the boundaries of Tajikistan because of ethnic kinships, the weakness of statehood and the absence of borders. Especially dangerous is a possible disintegration of Kazakhstan, whose population is mostly Russian. This in turn will endanger stability in Russia itself. ${ }^{12}$ There are different interpretations of the role of the Russian troops on the territories of Abkhazia, Moldova and Tajikistan. Some feel that they play the role of a mediator and a peacekeeping force. ${ }^{13}$ It is my contention, however, that to be a peacekeeping force, it would have to include forces of several CIS members. Yet at the present, it is comprised only of Russian troops, which arbitrarily assume the role of peacekeepers, often without an invitation and in spite of demands for their withdrawal. Their presence contributes to the escalation of the conflict and not its resolution, and will cause more bloodshed and displacement. $\square$

\section{NOTES}

1. Radio Free Europe Daily Report No. 185, September 25, 1992.

2. A. Mygranyan, "Real and Illusory Guidelines in Foreign Policy," Rossiiskaya Gazeta (August 4, 1992): 7. Andranik Mygranyan is a director of the CIS Centre of the Russian Academy of Sciences' Institute of International Economic and Political Research. 
3. Konstantin Eggert, "Russia in the role of 'Eurasian gendarme'?" Izvestia (August 7, 1992): 6 .

4. "Georgia Hits Coastal Town on Black Sea," The New Times (October 4, 1992).

5. The mountain peoples of Northern Caucasus, including Chechnya, Ingushetia, Kabardino-Balkaria, Northern Ossetia and Dagestan, have formed a federation. They demand a formation of a mostly Muslim confederation of independent states and the withdrawal of Russian troops from their territory. Abkhazia aspires to be a part of this confederation. In addition to sending volunteers to Abkhazia, the mountain people of Northern Caucasus have sent aid.

6. Olivia Ward "Shevardnadze, Yeltsin Caught in Escalating Caucasus Fight," The Toronto Star (October 4, 1992).

7. Igor Gamaunov, "Krovavya zgatva Anatolya Lukyanova," Novoe Russkoe Slovo (August 18, 1992).

8. Oazu Nantoi, "On Moldova and Not It Alone," Moscow News Weekly (November 29, 1992); Valery Litskaya, "Conquer or Kill," Moscow News Weekly (November 29, 1992); Alexander Kakotkin, "War with No Special Cause," Moscow News Weekly (November 27, 1992); "Russia between Dniestria's Two Banks," Moscow News Weekly (November 27, 1992); Ksenia Myalo, "Pridniestrovie: Vesna Tsveta Khaki," Novoe Vremya (November 16, 1992).

9. The Georgian and Moldovan foreign ministries said that the Abkhazia"Dniestria" alliance treaty just signed in Tiraspol promotes armed conflict, seeks to consolidate unlawful power structures within states, and violates national and international law as well as the spirit and goals of the UN and the CSCE. The precedent being set is potentially dangerous to the international system as a whole, the statements said (Radio Free Europe Daily Report, no. 21, February 2, 1993).

10. Yuri Zarakhovich, "War in a Vacuum," Time (October 12, 1992).

11. John Gray,"Anarchy Sweeps Tajik Capital," The Globeand Mail (October 26, 1992).

12. Vladimir Kulistikov, "Afghanistan Has Caught Up with Russia, But This Time in Tajikistan," New Times, no. 37 (November 1992).

13. Sophie Pons, "Russia Becomes Policeman and Mediator for CIS Nations," We 1 , no. 15 (October 5-18, 1992).
RESEARCH FELLOWSHIP AND AWARDS

\section{Centre for Refugee Studies York University}

\section{A. KATHLEEN PTOLEMY RESEARCH FELLOWSHIP}

An annual Can. \$15,000 Kathleen Ptolemy Research Fellowship has been set up to permit a visiting scholar from a developing country to undertake research on refugees. Scholars interested in the study of refugee women who are in need of protection, and demonstrate commitment to refugee rights advocacy or service to the disfranchised will be given priority.

\section{B. ANNUAL RESEARCH AWARDS}

The goal of these research awards is to provide funding to a number of graduate students while they undertake research projects under the auspices of the Centre for Refugee Studies. Eligible students are/will be registered full time in a graduate program at York University and who plan to do research in refugee and migration studies. International students are eligible to apply.

\section{VALUE OF AWARDS}

\section{i. Naomi Harder Refugee Award - Can. $\$ 15,000$}

The Naomi Harder Award may not be held in conjunction with an external scholarship or any other teaching or research assistantship.

\section{ii. General Refugee Awards - 5 awards of Can. \$9,000}

The General Refugee Awards may be held in conjunction with an external scholarship, but may not be held in conjunction with any other teaching or research assistantship.

Candidates should submit a curriculum vitae (resumé), academic records, two letters of reference and a sample of research or publications to the Centre for Refugee Studies, together with a statement of intent by March 15, 1993.

\section{VISITING SCHOLARS}

Visiting scholars may use the facilities at the Centre for Refugee Studies for short-term or long-term projects. Short-term projects are those that can be completed within a few weeks or months. We will provide visiting scholars with office space and a computer. Long-term research projects are for the duration of the academic year, which extends from September to April and are also eligible for funding support.

Please submit your applications to:

Helen Gross, Student/Faculty Liaison

Centre for Refugee Studies

Suite 322, York Lanes, York University

4700 Keele Street

North York, ON

Canada M3J 1P3

Tel: (416) 736-5663 - Fax: (416) 736-5837

E-mail via BITNET, address: REFUGE@YORKVM1 